\title{
The development of acid and pepsin (EC 3.4.23.1) secretory capacity in the pig; the effects of age and weaning
}

\author{
1. Studies in anaesthetized pigs \\ BY PETER D. CRANWELL \\ School of Agriculture, La Trobe University, Bundoora, Victoria 3083, Australia
}

(Received 28 June 1984-Accepted 12 March 1985)

1. The development of gastric secretory capacity of hydrochloric acid and pepsin (EC 3.4.23.1) was studied in thirty-eight Large White $\times$ Landrace pigs from the litters of six sows (three pairs of two), 9-38 $\mathrm{d}$ of age. The pigs of each pair of sows were born within $24 \mathrm{~h}$ of each other. The pigs of a litter were paired according to sex and size and cross-fostered, i.e. one pig from each pair was allocated to each sow.

2. One litter from each pair was reared entirely by the sow (milk-fed, MF) whereas the other litter was reared by the sow for $21 \mathrm{~d}$, but was allowed access to solid food $(210 \mathrm{~g}$ crude protein (nitrogen $\times 6 \cdot 25) / \mathrm{kg})$ at $12 \mathrm{~d}$ and was entirely dependent on solid food after $21 \mathrm{~d}$ (creep-fed, CF).

3. Following a 14-18 h fast, pigs were anaesthetized (Halothane-sodium pentobarbitone) and their stomachs perfused at a constant rate with Ringer solution. Gastric secretion was stimulated by intravenous infusion of betazole hydrochloride (Histalog) at $3 \mathrm{mg} / \mathrm{kg}$ per $\mathrm{h}$ for $2 \mathrm{~h}$. Hydrochloric acid and pepsin were measured in the perfusate which was collected at 15 -min intervals.

4. There were significant positive correlations between stomach weight and body-weight for both MF and CF pigs. The slope of the regression line for $\mathrm{CF}$ pigs was significantly greater than that for MF pigs $(P<0.01)$.

5 . There were significant positive correlations between maximal acid output and stomach weight for both MF and $\mathrm{CF}$ pigs.

6. There were significant positive correlations between maximal pepsin output and stomach weight for both MF and CF pigs. The slope of the regression line for CF pigs was significantly different from that for MF pigs $(P<0.01)$. There were also significant positive correlations between maximal pepsin output per unit stomach weight and stomach weight for both $\mathrm{MF}$ and $\mathrm{CF}$ pigs.

7. The pattern of development of pepsin secretory capacity in both CF and MF pigs was different from that for acid secretion. Maximal outputs of acid per unit stomach weight for MF and CF pigs remained relatively constant. Maximal outputs of pepsin per unit stomach weight and per unit body-weight increased with age for both $\mathrm{MF}$ and $\mathrm{CF}$ pigs.

8. The results indicate that pigs given access to solid food before weaning and weaned on to solid food have heavier stomachs and greater acid and pepsin secretory capacity than pigs fed entirely on sows' milk.

Many of the earlier studies on development of the stomach in the pig reviewed by Cranwell et al. (1976), Kidder \& Manners (1978) and Simoes-Nunes (1982) indicated that acid secretion was not well-developed until the pigs were 2-4 weeks old. However, the failure by some of the earlier workers to detect free hydrochloric acid in stomach contents may not necessarily be due to the absence of acid secretion but in fact due to the buffering properties of milk, saliva, gastric mucus and regurgitated bile, and pancreatic juice. Conversely, evidence of marked acidity, based on $\mathrm{pH}$ measurements, may have reflected the presence of organic acids produced by gastric fermentation (Friend et al. 1963) rather than hydrochloric acid secretion. It is also possible that the presence of large amounts of lactic acid in the stomach may partly or completely inhibit hydrochloric acid secretion (Cranwell et al. 1976).

That the stomach of the newborn pig is capable of secreting hydrochloric acid has been demonstrated by Forte et al. (1975) using an in vitro technique and by Cranwell \& Titchen (1974), Cranwell et al. (1976), Tudor et al. (1977) and Tudor (1983) using three different in vivo techniques. However, the acid secretory capacity of the stomach of the newborn pig is significantly lower than that of older pigs (Titchen et al. 1980; Cranwell, 1984) and 
secretory capacity appears to increase with age during the first 4-5 weeks of life (Cranwell \& Titchen, 1976).

The study of the development of pepsin secretion in the newborn pig has been mainly confined to determinations of the proteolytic activity of extracts of gastric mucosa and gastric contents (Lewis et al. 1957; Braude et al. 1958; Hartman et al. 1961; Seve \& Laplace, 1975; Decuypere et al. 1978; Baintner \& Nemeth, 1982; Efird et al. 1982; Pelletier et al. 1983) and to studies on secretion from separated Heidenhein gastric pouches (Cranwell \& Titchen, 1976). The results of these studies indicate that the gastric mucosa and gastric juice of the newborn pig contain little or no proteolytic activity and that the amount of pepsin in the gastric mucosa and its concentration in gastric juice increases with age, with a dramatic increase occurring 3-4 weeks after birth. Foltmann et al. (1978) have found that the stomach mucosa of the newborn pig rarely contains any of the pepsins found in the adult pig but that it does contain a proteinase (pig chymosin) that is immunologically closely related to calf chymosin. More recently Foltmann et al. (1981) found that chymosin concentration in the gastric mucosa of the pig was greatest at birth and declined during the first 2 weeks of life, and that pepsin (EC 3.4.23.1) concentration is very low during this period and increases markedly 2-4 weeks after birth.

Apart from the studies by Merritt \& Brooks (1970) in the 8-26-week-old miniature pig there is little information on the effects of age or diet on the development of gastric secretory capacity in the pig. Starovojtov (1956) and Hartman et al. (1961) found that introduction of solid food causes an increase in stomach weight, potential pepsin secretory capacity and acid secretion. More recently Decuypere et al. (1978) found that the increase in proteolytic activity in gastric contents after 2 weeks of age was more pronounced in pigs given solid food than in sucking pigs.

The aims of the experiments reported here were to study the development of the capacity of the stomach to secrete hydrochloric acid and pepsin and to determine what effects introduction of solid food and weaning have on this development. A preliminary report of these experiments has been made (Cranwell, 1977).

\section{EXPERIMENT A L}

\section{Pigs and their treatment}

Animals and housing. Six litters of Large White $\times$ Landrace pigs were used in this experiment. Pairs of sows having the same expected farrowing date were obtained from a commercial piggery 1 month before they were expected to farrow. The sows were housed singly in huts provided with farrowing rails; the creep area was provided with an infrared lamp as an additional source of heat, and sawdust was used for bedding during the week after farrowing.

During the day following farrowing the pigs of each litter were weighed, numbered and paired according to sex and size. At $24 \mathrm{~h}$ after the second sow of each pair farrowed the litters were cross-fostered, i.e. one pig from each pair was allocated to each sow. Each rearranged litter was placed together in a wire cage for $6 \mathrm{~h}$ and then returned to the sow. The pigs were accepted by the sows and quickly established their teat order.

Diets and feeding. One litter from each pair was reared entirely by the sow (milk-fed, MF; litters $1 \mathrm{M}, 4 \mathrm{M}$ and $5 \mathrm{M}$ ) whereas the other litter was reared by the sow for $21 \mathrm{~d}$, but was allowed access to solid food at $12 \mathrm{~d}$ and was entirely dependent on solid food after $21 \mathrm{~d}$ (creep fed, CF; litters $2 \mathrm{C}, 3 \mathrm{C}$ and $6 \mathrm{C}$ ). The composition of the creep diet given to the CF litters is presented in Table 1 ; the same diet was used for the duration of the experiment. Following weaning at $21 \mathrm{~d}$ of age the CF litters were moved to an air-conditioned room where they were housed in a $1.85 \times 1.85 \mathrm{~m}$ pen equipped with a self-feeder and a drinker. 
Table 1. Ingredients and composition of the creep diet given to pigs

\begin{tabular}{lclc}
\hline \multicolumn{1}{c}{ Ingredients } & $(\mathrm{g} / \mathrm{kg})$ & \multicolumn{1}{c}{ Composition } \\
\hline Hulled oats & 140 & Dry matter $(\mathrm{g} / \mathrm{kg})$ & 920 \\
Wheat & 110 & Gross energy $(\mathrm{MJ} / \mathrm{kg})$ & $18 \cdot 41$ \\
Maize & 120 & Digestible energy $(\mathrm{MJ} / \mathrm{kg})$ & $15 \cdot 32$ \\
Soya bean & 100 & Crude protein $($ nitrogen $\times 6 \cdot 25)(\mathrm{g} / \mathrm{kg})$ & 210 \\
Whole-milk powder & 100 & Lipid $(\mathrm{g} / \mathrm{kg})$ & 46 \\
Skim-milk powder & 300 & Fibre $(\mathrm{g} / \mathrm{kg})$ & 22.5 \\
Soft brown sugar & 100 & & \\
Christmas Island phosphate & 2.5 & & \\
Calcium stearate & 19 & & \\
Salt (sodium chloride) & 1.5 & & \\
Vitamin and trace mineral mixture* & 5 & & \\
Selenium premix $\dagger$ & 1.5 & & \\
Mecadox $\ddagger$ & 0.5 & & \\
\hline
\end{tabular}

* Contained (mg): retinol 3.3, chlorecalciferol 0.045, vitamin E 20, thiamin 2, riboflavin 6, biotin 0.19, pyridoxine 10 , cyanocobalamin $0 \cdot 020$, calcium $d$-pantothenate 14.4 , nicotinic acid 32 , phylloquinone 4 , pteroylmonoglutamic acid 2 , ascorbic acid 177.5, copper (as sulphate) $3 \cdot 75$, manganese (as oxide) $9 \cdot 3$, zinc (as oxide) 48 , iron (as sulphate) 56 , magnesium (as oxide) 162, iodine (as potassium iodide) $4 \cdot 75$, cobalt (as carbonate) $2 \cdot 47$, calcium phosphate 1333. This mixture was made up to $5 \mathrm{~g}$ with ground wheat.

$\uparrow$ Contained $0.436 \mathrm{mg}$ selenium (as sodium selenite) made up to $1.5 \mathrm{~g}$ with ground wheat.

$\ddagger$ Contained $50 \mathrm{mg}$ Carbadox, Pfizer Agricare Pty Ltd, Moorabbin, Victoria, Australia.

The pen was raised $0.4 \mathrm{~m}$ above the floor; one-third of the floor area of the pen consisted of mesh wire and the remaining two-thirds was of wood. An infrared lamp was provided as an additional source of heat; no bedding was provided.

The sows of litters $1 \mathrm{M}, 4 \mathrm{M}$ and $5 \mathrm{M}$ were fed twice daily in a yard with the pigs locked away in the hut. After each feeding $(1 \mathrm{~h})$ all the remaining sow food was removed from the feeder and any spilt food was hosed away. The sows of litters $2 \mathrm{C}, 3 \mathrm{C}$ and $6 \mathrm{C}$ were fed ad lib., food was available continuously in a feeder in the yard.

\section{Perfusion experiments}

Gastric perfusion experiments were carried out in nineteen litter-mate pairs of pigs, which were allotted to three age-groups: age-group 1, 9-12 d old, four pairs; age-group 2, 18-21 d old, six pairs; age-group 3, 27-38 d old, nine pairs. The eight pigs in age-group 1 were two each from sows $3 \mathrm{C}, 4 \mathrm{M}, 5 \mathrm{M}$ and $6 \mathrm{C}$. The twelve pigs in age-group 2 were two each from sows $1 \mathrm{M}, 2 \mathrm{C}, 3 \mathrm{C}, 4 \mathrm{M}, 5 \mathrm{M}$ and $6 \mathrm{C}$. The eighteen pigs in age-group 3 (nos. of pigs in parentheses) were from sows $1 \mathrm{M}(6), 2 \mathrm{C} \mathrm{(2),3C} \mathrm{(4),} \mathrm{4M} \mathrm{(4),} \mathrm{5M} \mathrm{(1)} \mathrm{and} \mathrm{6C} \mathrm{(1).}$

Surgical preparation. Each litter-mate pair was removed from its source of food 14-18 h before the experiments. The pigs were housed separately in cages in a darkened, air-conditioned room with air temperature maintained at $30^{\circ}$. They were not disturbed until they were weighed immediately before the experiment.

Anaesthesia was induced with an intra-peritoneal dose of sodium pentobarbitone $(30 \mathrm{mg} / \mathrm{kg}$ ) and was maintained with Halothane (BP) inhaled through a small Hall-type dog mask (BOC, London UK) using a concentration of $20 \mathrm{ml} / \mathrm{l}$ carbogen (Fluotec 3 vapourizer; Cyprane Ltd, Keighley UK; setting of 2, with carbogen flow up to $500 \mathrm{ml} / \mathrm{min}$ ). A midline incision was made in the neck and a polyethylene catheter was tied into the left internal jugular vein. Anaesthesia was then maintained with doses of 5-10 mg sodium pentobarbitone $/ \mathrm{kg}$ intravenously as required.

The trachea was cannulated with a ' $T$ '-shaped glass cannula, a polyvinyl tube was tied 
into the oesophagus and a polyethylene catheter was tied into the left carotid artery. The abdomen was opened through a midline incision, the bile duct was located and ligated, a silastic tube was passed into the stomach through the duodenum and tied firmly in place near the pyloro-duodenal junction.

Gastric perfusion experiments. After closure of the abdomen the stomach was washed free of contents with $500 \mathrm{ml}$ Ringer solution $\left(147.5 \mathrm{mmol} \mathrm{Na}{ }^{+}, 4 \mathrm{mmol} \mathrm{K}+, 4.5 \mathrm{mmol} \mathrm{Ca}{ }^{2+}\right.$, $156 \mathrm{mmol} \mathrm{Cl}^{-}$) and was then perfused with Ringer solution at 100,200 or $300 \mathrm{ml} / \mathrm{h}$ using a perfusion pump connected to the polyvinyl tube in the oesophagus. After the initial washout, fluid was collected continuously into a measuring cylinder. At 15-min intervals the amount collected was recorded, mixed, the $\mathrm{pH}$ measured and a $15 \mathrm{ml}$ sample retained for total acid and pepsin estimation. Following the initial 45-75 min infusion of sterile, pyrogen-free Ringer solution (Travenol Laboratories, Sydney, Australia) into the jugular vein at $2.6 \mathrm{ml} / \mathrm{h}$, betazole hydrochloride (Histalog; Eli Lilly, Indianapolis, Indiana, USA) in Ringer solution was infused at a dose rate of $3 \mathrm{mg} / \mathrm{kg}$ per $\mathrm{h}$ for $2 \mathrm{~h}$. This dose rate was calculated to be equivalent to the dose of histamine base $(60 \mu \mathrm{g} / \mathrm{kg}$ per h) found by Merritt $\&$ Brooks (1970) to induce maximum gastric acid and pepsin secretion in the miniature pig. According to the manufacturer (Eli Lilly and Co.) a dose of $50 \mu \mathrm{g}$ Histalog is comparable to $1 \mu \mathrm{g}$ histamine base. It has subsequently been confirmed that the acid secretory response to Histalog in young pigs is maximal at a dose rate of $3 \mathrm{mg} / \mathrm{kg}$ per h (Cranwell \& Stuart, 1983a).

At the conclusion of the perfusion experiment the pigs were killed with an overdose of sodium pentobarbitone. The stomach was immediately removed, emptied of any residual fluid and weighed.

\section{Analytical procedures}

$p H$. The $\mathrm{pH}$ of the gastric perfusate was measured electrometrically using a model pH M51 meter and a combined electrode GK2321C (Radiometer, Copenhagen, Denmark).

Acidity. Acidity of the gastric perfusate was measured by potentiometric titration with $2.5 \mathrm{~mm}-\mathrm{NaOH}$ to $\mathrm{pH} 7.00$ under carbon dioxide-free conditions. The highest consecutive 30 min outputs were doubled to express maximum hourly output, i.e. $\mathrm{mmol} \mathrm{H}^{+} / \mathrm{h}$.

Pepsin. The estimation of pepsin content of gastric perfusate was carried out on the day following perfusion experiments; samples were stored at $4^{\circ}$ until analysed. Pepsin concentration was determined by the method described by Fourie et al. (1974) with the exception that the gastric perfusate was not further diluted. Again the highest consecutive $30 \mathrm{~min}$ outputs were doubled to express maximum hourly output, i.e., $\mathrm{k}$ units $/ \mathrm{h}$. A unit (u) is defined as being equivalent to a change in absorbance at $280 \mathrm{~nm}\left(\Delta A_{280}\right)$ of 0.001 per min at $\mathrm{pH} 2.0$ at $37^{\circ}$, measured as trichloroacetic acid-soluble products using haemoglobin as substrate.

\section{Statistical analysis}

The BAR3 program developed at the University of New England Computer Centre by Professor E. J. Burr was used for linear regression analysis and analyses of variance. $F$ tests were used to test for statistical differences between slopes and intercepts of regression estimates. The paired $t$ statistic (Ostle, 1963) was used to estimate the significance of differences between treatments within age-groups, the standard errors were based on the interaction between litters and treatments at a given age. The $t$ statistic for two means (Brownlee, 1965) was used to estimate the significance of differences between age-groups within treatments, the standard errors were based on the variation between pigs within age groups and treatments. 


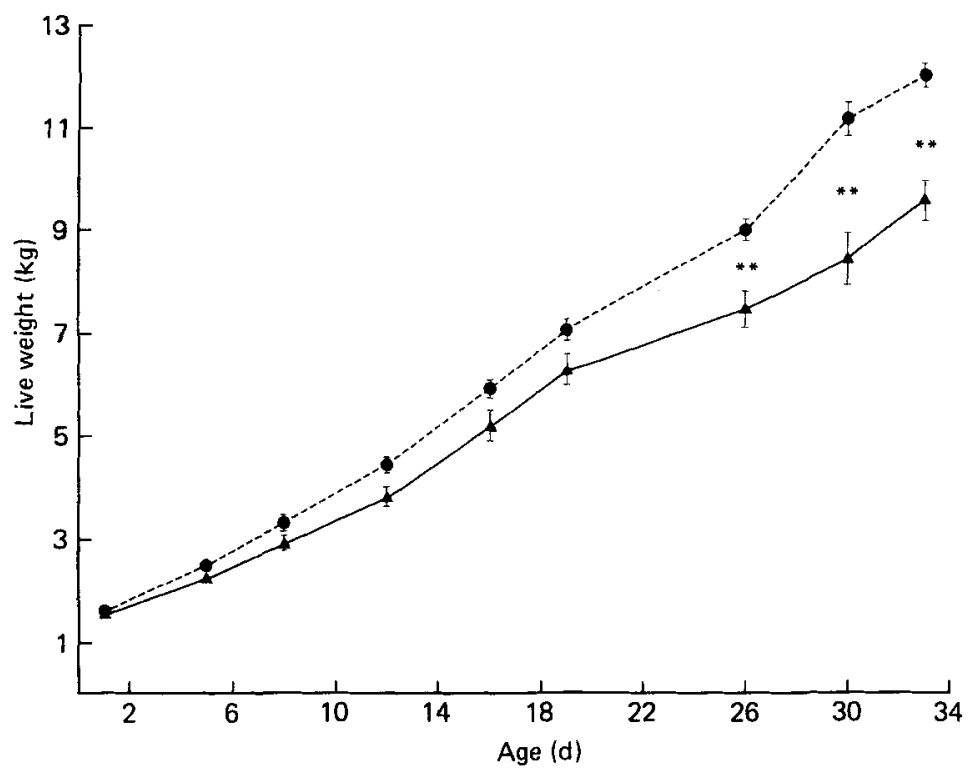

Fig. 1. Live weight (g) of pigs of each treatment $v$. age (d). (A), Creep-fed pigs; (O), milk-fed pigs. Difference between means was significant: ${ }^{* *} P<0.01$. Points are mean values, with their standard errors represented by vertical bars.

\section{RESULTS}

\section{Live weight and growth rate}

All pigs grew satisfactorily while they were with the sow. The creep-fed (CF) pigs appeared not to grow as quickly as the milk-fed (MF) pigs during the first $19 \mathrm{~d}$ of life (Fig. 1), but their live weights were not significantly different during that period. During the 2 weeks following weaning, $\mathrm{CF}$ pigs grew significantly more slowly $(P<0.01)$ than MF pigs.

\section{Stomach weight and body-weight}

There were significant correlations between stomach weight and body-weight for both MF and CF pigs. The regression equations were:

MF pigs:

$$
Y=5.22(\mathrm{SE} 0.407) X-0.76(\text { SE } 3.463), \quad r^{2} 0.90, P<0.001, \text { df } 17,
$$

CF pigs:

$$
Y=7.33 \text { (SE 0.578) } X-6.72 \text { (SE 4.227), } \quad r^{2} 0.90, P<0.001 \text {, df } 17,
$$

where $X$ is body-weight $(\mathrm{kg})$ and $Y$ is stomach weight $(\mathrm{g})$. The slope of the regression line for CF pigs was significantly greater than that for MF pigs $(P<0.01)$.

The stomach weight: body-weight values in pigs of both treatments were significantly lower in age-group 2 than in the pigs of age-group 1 (Table 2). Following weaning on to solid food at $21 \mathrm{~d}$, the CF pigs of age-group 3 had significantly more stomach tissue per unit body-weight than those in the previous age-group and the MF pigs in age-group 3.

\section{Acid secretion}

Resting secretion. Acid was found in the initial washout from each pig, as well as in all subsequent 15 min collections. The mean amount of acid $\left(\mu \mathrm{mol} \mathrm{H}^{+}\right)$in the washout from 
Table 2. Stomach weight and stomach weight:body-weight values in creep-fed and milk-fed pigs

(Mean values with their standard errors)

\begin{tabular}{|c|c|c|c|c|c|c|c|c|}
\hline \multirow[t]{2}{*}{$\begin{array}{c}\text { Age-group... } \\
\text { Age (d)... } \\
\text { No. of pigs } / \text { treatment... }\end{array}$} & \multicolumn{2}{|c|}{$\underset{4}{1}+12 \ddagger$} & & \multicolumn{2}{|c|}{$\begin{array}{c}2 \\
18-21 \\
6\end{array}$} & & \multicolumn{2}{|c|}{$\begin{array}{c}3 \\
27-38 \\
9\end{array}$} \\
\hline & Mean & SE & & Mean & $\mathbf{S E}$ & & Mean & SE \\
\hline \multicolumn{9}{|l|}{ Stomach wt (g) } \\
\hline Milk-fed & $20 \cdot 0$ & 2.67 & $*$ & $29 \cdot 5$ & 1.54 & **** & $56 \cdot 2$ & $4 \cdot 31$ \\
\hline Creep-fed & 17.5 & 0.72 & *** & $29 \cdot 8$ & 1.72 & **** & $62 \cdot 9$ & $4 \cdot 22$ \\
\hline \multicolumn{9}{|l|}{ Stomach wt: body-wt $(\mathrm{g} / \mathrm{kg})$} \\
\hline Milk-fed & $5 \cdot 9$ & 0.26 & $* * *$ & $4 \cdot 7$ & 0.08 & & $\begin{array}{l}5 \cdot 2 \\
++4\end{array}$ & $0 \cdot 23$ \\
\hline Creep-feed & $6 \cdot 2$ & $0 \cdot 31$ & * & $5 \cdot 1$ & 0.22 & *** & 6.9 & $0 \cdot 26$ \\
\hline
\end{tabular}

¥ Creep-fed pigs received only sows' milk up to $12 \mathrm{~d}$.

Differences between age-groups within treatments were significant: ${ }^{*} P<0.05,{ }^{* * *} P<0.001$.

Differences between treatments within age-groups were significant: $\dagger+\dagger P<0.001$.

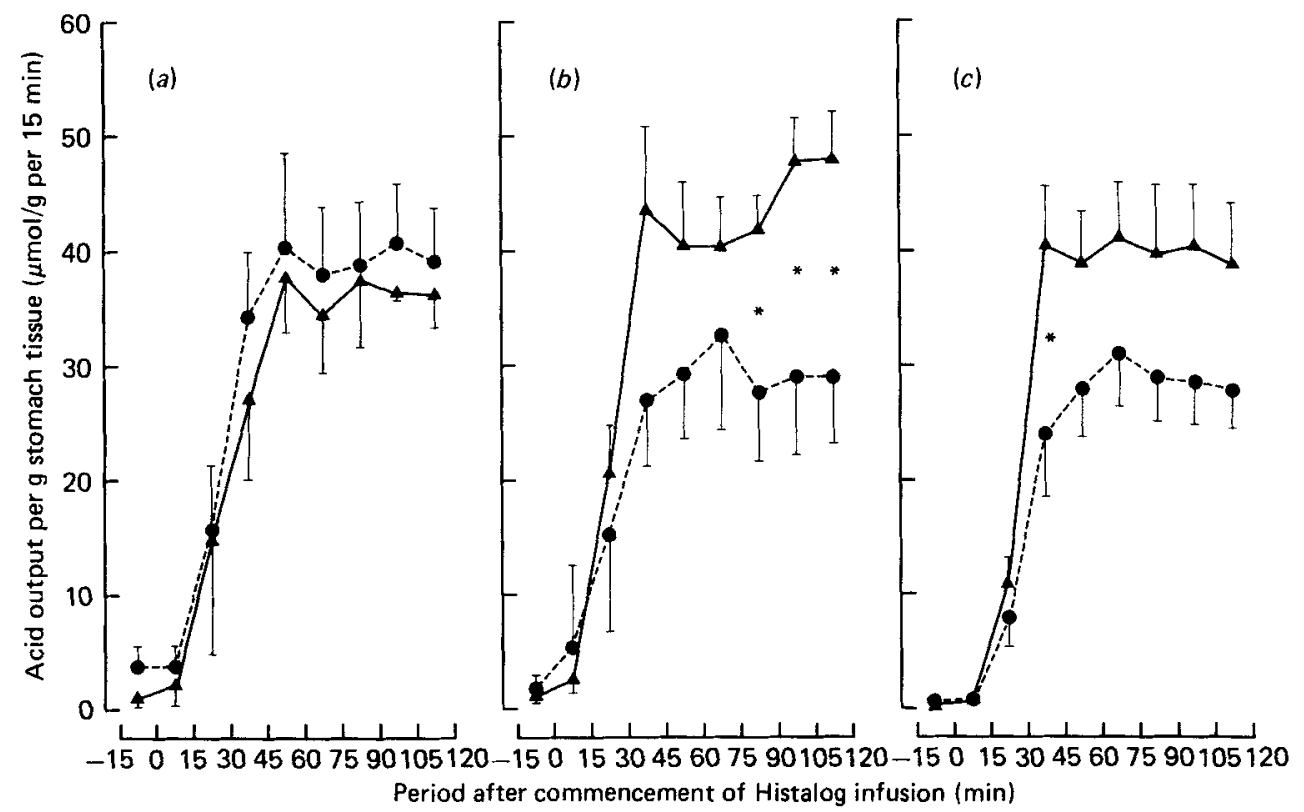

Fig. 2. Acid release ( $\mu \mathrm{mol} / \mathrm{g}$ per $15 \mathrm{~min}$ ) per unit stomach weight $(\mathrm{g})$ during the $15 \mathrm{~min}$ periods before and following commencement of continuous betazole hydrochloride (Histalog) infusion $(0 \mathrm{~min})$ at $3 \mathrm{mg} / \mathrm{kg}$ per $\mathrm{h}$ in milk-fed pigs $(\boldsymbol{O})$ and creep-fed pigs $(\boldsymbol{\Delta})$. Points are mean values, with their standard errors represented by vertical bars. (a), Age-group 1, 9-12d old; (b), age-group 2, 18-21 d old; (c), age-group 3, 27-38 d old. Difference between treatments within 15 min periods was significant: * $P<0.05$. 


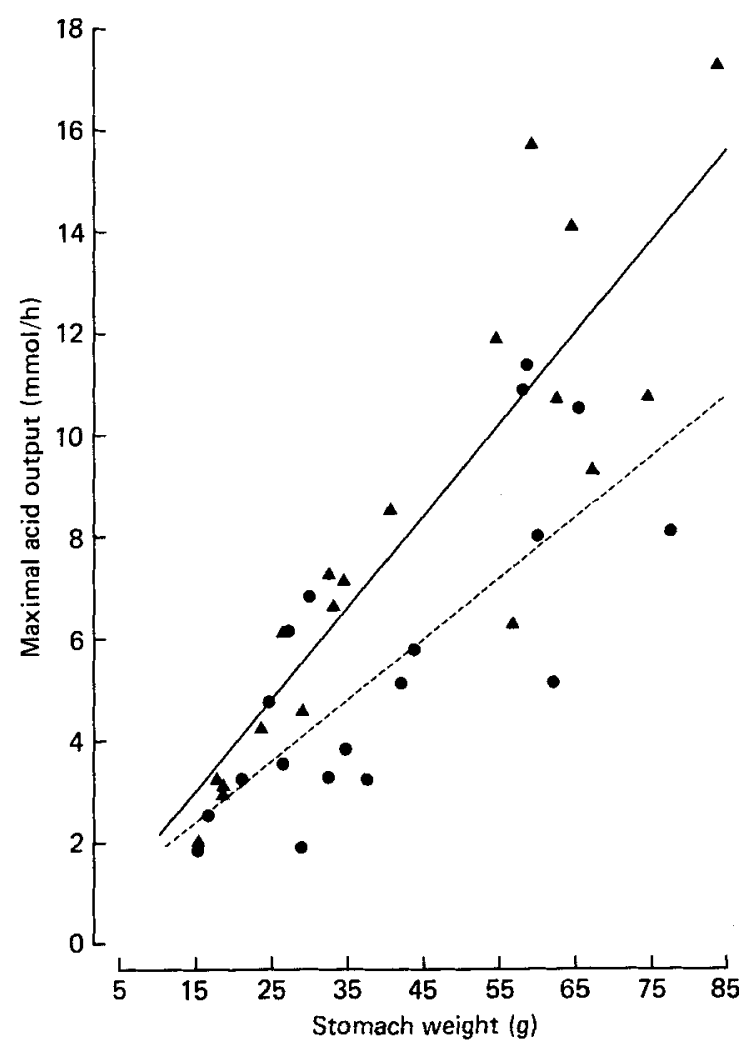

Fig. 3. Linear regression of maximal acid output (mmol/h) v. stomach weight (g) of milk-fed pigs (O) and creep-fed pigs $(\boldsymbol{\Delta})$. The regression equations were:

Milk-fed pigs (-.--):

$Y=0.12$ (SE 0.025) $X+0.54$ (SE 1.213 ), $\quad r^{2} 0.60, P<0.001$, df 17 .

Creep-fed pigs $\left(-\frac{-}{-}\right)$ :

$Y=0.18$ (SE 0.024) $X+0.32($ SE 1.327$), \quad r^{2} 0.72, P<0.001$, df 17.

the pigs of each age-group were; 1, 433 (SE 75.4) (range 182-849); 2, 505 (SE 95.9) (range 176-1192); 3, 1020 (SE 211.8) (range 354-3211). The differences between treatments within age-groups were not significant but between age-groups the differences between age-group 3 and the other age-groups were significant $(P<0.05)$.

The mean resting value for acid release for all pigs during the $45 \mathrm{~min}$ before commencement of Histalog infusion was 7.4 (SE 2.07) $\mu \mathrm{mol} / \mathrm{kg}$ per $15 \mathrm{~min}$ (range 1-66). Differences between treatments within age-groups and between age-groups within treatments were not significant.

Histalog-stimulated acid secretion. Secretory responses were not evident in all pigs until 30 min after commencement of Histalog infusion (Fig. 2). This would indicate that a threshold blood concentration of Histalog must be reached before stimulation of acid secretion occurs. Time taken to reach the maximal rate of acid output varied from 60 to 120 min after the commencement of Histalog infusion.

In all pigs two phases of the secretory response were evident during continuous infusion of Histalog. The first comprised a steep rise in acid secretion to an initial peak value at 45-60 min after commencement of Histalog infusion and the second, a levelling off of secretion at a rate similar to that of the initial peak value (Fig. 2). 
Table 3. Maximal acid output in creep-fed and milk-fed pigs during continuous intravenous betazole hydrochloride (Histalog) infusion ( $3 \mathrm{mg} / \mathrm{kg}$ per h)

(Mean values with their standard errors)

\begin{tabular}{|c|c|c|c|c|c|c|c|c|}
\hline \multirow[t]{2}{*}{$\begin{array}{c}\text { Age-group ... } \\
\text { Age }(\mathrm{d}) \ldots \\
\text { No. of pigs/treatment... }\end{array}$} & \multicolumn{2}{|c|}{$\begin{array}{c}1 \\
9-12 \ddagger\end{array}$} & & \multicolumn{2}{|c|}{$\begin{array}{c}2 \\
18-21 \\
6\end{array}$} & & \multicolumn{2}{|c|}{$\begin{array}{c}3 \\
27-38 \\
9\end{array}$} \\
\hline & Mean & $\mathrm{SE}$ & & Mean & $\mathrm{SE}$ & & Mean & SE \\
\hline \multicolumn{9}{|l|}{$\begin{array}{l}\text { Maximal acid output } \\
\left(\mathrm{mmol} \mathrm{H}^{+} / \mathrm{h}\right)\end{array}$} \\
\hline Milk-fed & $3 \cdot 4$ & 0.95 & & $4 \cdot 0$ & 0.67 & * & $7 \cdot 6$ & 0.98 \\
\hline Creep-fed & $2 \cdot 8$ & 0.28 & ** & 6.0 & 0.54 & * & $11 \cdot 6$ & $1 \cdot 18$ \\
\hline \multicolumn{9}{|l|}{$\begin{array}{l}\text { Per unit stomach wt } \\
\left(\mathrm{mmol} \mathrm{H} \mathrm{H}^{+} / \mathrm{g} \text { per } \mathrm{h}\right)\end{array}$} \\
\hline Milk-fed & $0 \cdot 16$ & 0.023 & & $0 \cdot 14$ & 0.025 & & $0 \cdot 13$ & 0.014 \\
\hline Creep-fed & 0.16 & 0.011 & * & 0.20 & 0.011 & & 0.19 & 0.017 \\
\hline \multicolumn{9}{|l|}{$\begin{array}{l}\text { Per unit body-wt } \\
(\mathrm{mmol} \mathrm{H} / \mathrm{kg} \text { per } \mathrm{h})\end{array}$} \\
\hline Milk-fed & 0.97 & $0 \cdot 171$ & & $\begin{array}{c}0.65 \\
\dagger\end{array}$ & $0 \cdot 115$ & & $\begin{array}{c}0.69 \\
+\dagger\end{array}$ & 0.067 \\
\hline Creep-fed & 0.98 & 0.046 & & 1.03 & 0.081 & & $1 \cdot 28$ & $0 \cdot 110$ \\
\hline
\end{tabular}

$\ddagger$ Creep-fed pigs received only sows' milk up to $12 \mathrm{~d}$.

Differences between age-groups within treatments were significant: ${ }^{*} P<0.05 ;{ }^{* *} P<0.01$.

Differences between treatments within age-groups were significant: $\uparrow P<0.05 ; \uparrow+P<0.0$.

There were significant correlations between maximal acid output and stomach weight for both MF and CF pigs (Fig. 3). This indicates that there was a significant increase in maximal acid output with increasing stomach size in the pigs of both treatments.

The gastric acid secretory capacity of pigs of both treatments in age-group 1 were not significantly different (Table 3, Fig. 2). This was to be expected as all the pigs in age-group 1 received only sows' milk, i.e. there were no treatment differences until the pigs were $13 \mathrm{~d}$ old. In MF pigs, there was a small, but not significant, decrease in acid secretory capacity per unit stomach weight in the two older groups of animals (Table 3, Fig. 2). The mean acid secretory capacity per unit stomach weight for MF pigs of age-groups 2 and 3 was 0.14 (SE 0.011) $\mathrm{mmol} / \mathrm{g}$ per $\mathrm{h}$, and for CF pigs was 0.19 (SE 0.011) $\mathrm{mmol} / \mathrm{g}$ per $\mathrm{h}$; the difference was significant $(P<0.01 ;$ Fig. 2$)$. In the pigs given access to creep feed, while still with the sow (age-group 2), acid secretory capacity per se and per unit stomach weight were significantly greater than in the pigs of the younger group. The CF pigs of age-groups 2 and 3 had significantly greater gastric acid secretory capacities per unit body-weight than MF pigs of these groups (Table 3).

\section{Pepsin secretion}

Resting secretion. Pepsin concentration was measured in the sample preceding the start of Histalog infusion, but not in earlier samples or in the initial washout.

Pepsin was found in the resting sample from each pig as well as in all subsequent $15 \mathrm{~min}$ collections. The mean amount of pepsin in the resting samples from the pigs of each age-group were: $1,0 \cdot 16$ (SE 0.028); $2,0 \cdot 70$ (SE 0.184); 3, 1.08 (SE 0.086) ku/15 min. Since the differences between treatments within each age-group were not significant, the values were pooled for each age-group. Pepsin output in resting samples increased with age, and the differences 


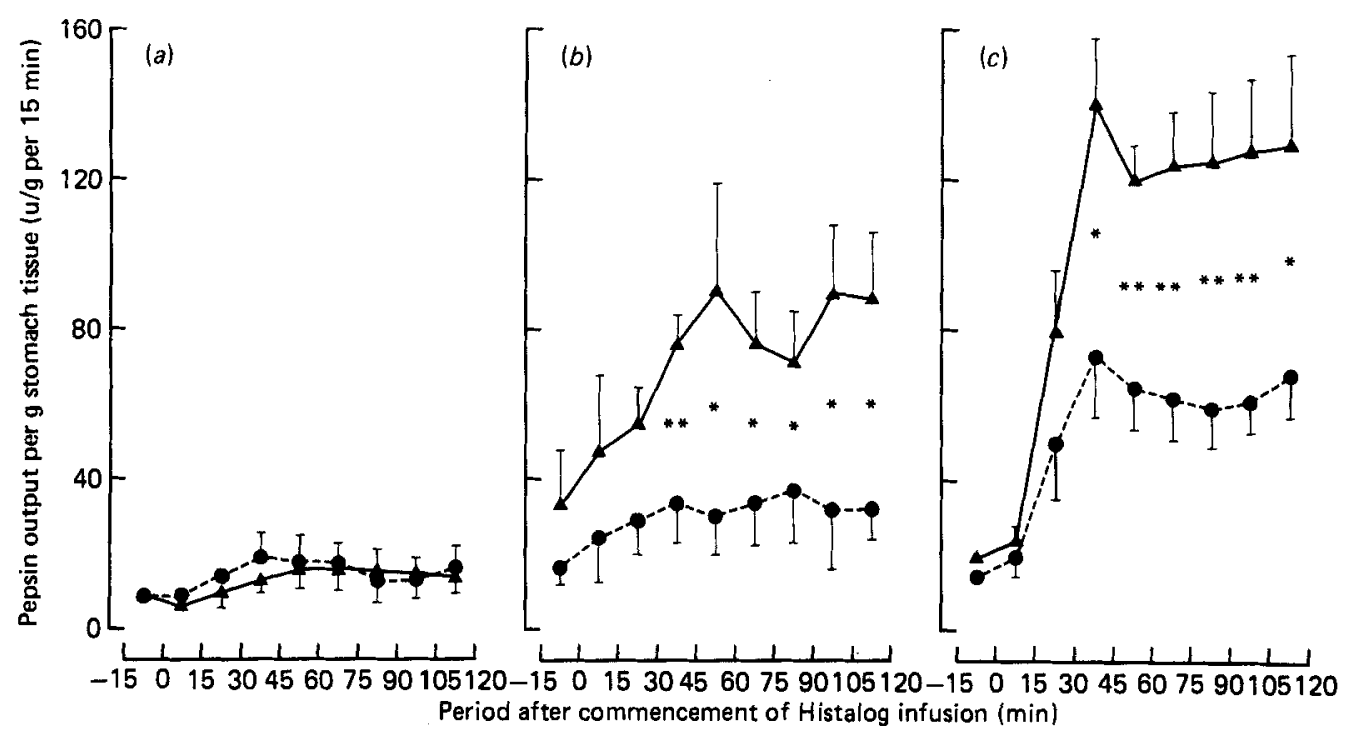

Fig. 4. Pepsin (EC 3.4.23.1) release (u/g per $15 \mathrm{~min}$ ) per unit stomach weight $(\mathrm{g})$ during the $15 \mathrm{~min}$ periors before and following commencement of continuous betazole hydrochloride (Histalog) infusion $(0 \mathrm{~min})$ at $3 \mathrm{mg} / \mathrm{kg}$ per $\mathrm{h}$ in milk-fed pigs (O) and creep-fed pigs (A). Points are mean values, with their standard errors represented by vertical bars. (a), Age-group 1, 9-12 d old; (b), age-group 2, 18-21 d old; (c) age-group 3, 27-38 d old.

Differences between treatments within 15 min periods were significant: ${ }^{*} P<0.05$, $^{* *} P<0.01$.

$\mathrm{u}$, Unit of activity defined as equivalent to a $\Delta A_{2 \mathrm{s0}}$ of $0.001 / \mathrm{min}$ at $\mathrm{pH} 2 \cdot 0,37^{\circ}$.

between age-group 3 and age-group 2, and between age-group 2 and age-group 1 were significant $(P<0.05)$.

Histalog-stimulated pepsin secretion. There was a small, but non-significant increase in pepsin output above pre-infusion levels during the $2 \mathrm{~h}$ Histalog infusion in the pigs of both treatments in age-group 1 (Fig. 4). In age-group 2 the CF pigs showed a more definite secretory response than those in the younger age-group; pepsin output was significantly greater than pre-infusion levels by the third 15 min period after commencement of Histalog infusion $(P<0.05)$. However, at no time during Histalog infusion was pepsin output significantly greater than pre-infusion levels in the MF pigs of age-group 2 . There were well defined, two-phase pepsin secretory responses in pigs of both treatments in age-group 3 with a steep rise in output to an initial peak value at $45 \mathrm{~min}$ after commencement of Histalog infusion, followed by a levelling off of secretion at a rate similar to that of the initial peak value (Fig. 4).

There were significant correlations between maximal pepsin output and stomach weight for both MF and CF pigs (Fig. 5). The slope of the regression line for CF pigs was significantly different $(P<0.01)$ from that for MF pigs. There were also significant correlations between maximal pepsin output per unit stomach weight and stomach weight for both MF and CF pigs. The regression equations were:

MF pigs:

$$
Y=0.006(\text { SE } 0.0014) X-0.018(\text { SE } 0.0614), \quad r^{2} 0.54, P<0.001 \text {, df } 17,
$$

CF pigs:

$$
Y=0.009 \text { (SE 0.0021) } X+0.087(\text { SE } 0 \cdot 1047), \quad r^{2} 0.49, P<0.001 \text {, df } 17 \text {, }
$$




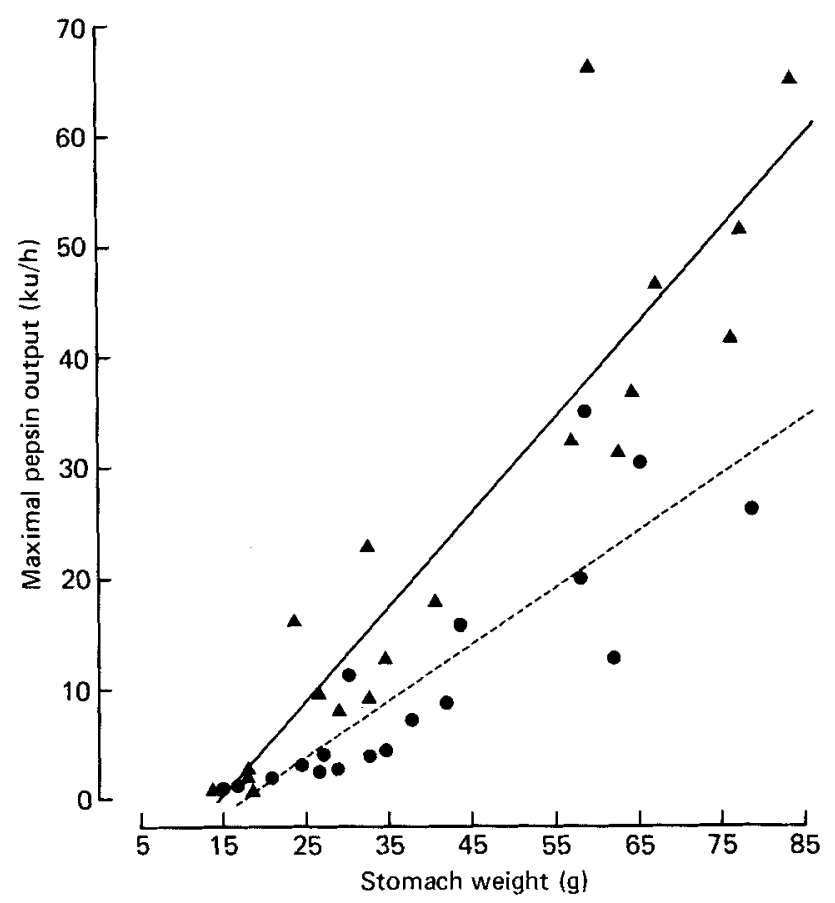

Fig. 5. Linear regression of maximal pepsin (EC 3.4.23.1) output (ku/h)v. stomach weight (g) of milk-fed pigs $(\boldsymbol{O})$ and creep-fed pigs $(\boldsymbol{A})$. The regression equations were:

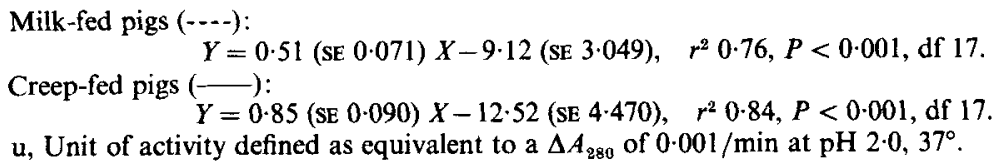

where $X$ is stomach weight (g) and $Y$ is maximal pepsin output per unit stomach weight $(\mathrm{ku} / \mathrm{g})$. Thus, significant increases in maximal pepsin output with increasing stomach size and maximal pepsin output per unit stomach weight with increasing stomach size occurred in the pigs of both treatments. The increase in maximal pepsin output with increasing stomach size occurred at a significantly faster rate in the CF pigs.

The pattern of development of pepsin secretion in both CF and MF pigs was quite different from that seen for acid secretion. This was mainly reflected in the changes in maximal outputs per unit stomach weight and per unit live weight with age (Tables 3 and 4, Figs. 2 and 4).

\section{DISCUSSION}

\section{Live weight and growth rate}

A number of factors may have been implicated in the greater live weight of MF pigs compared with CF pigs in the periods after weaning. Usually the amount of milk produced by the sow is inadequate for satisfactory growth of the litter after 2-3 weeks of age (Agricultural Research Council, 1967). However, as each pig was used only once the number of pigs per litter decreased during the experimental period. From 3 to 4 weeks there were four pigs per litter and in the final 7-10 d of the experiment there were two pigs per litter. Consequently, as the MF pigs got older they had access to an increasing number of 
Table 4. Maximal pepsin (EC 3.4.23.1) output in creep-fed and milk-fed pigs during continuous intravenous betazole hydrochloride (Histalog) infusion ( $3 \mathrm{mg} / \mathrm{kg} \mathrm{per} \mathrm{h}$ )

(Mean values with their standard errors)

\begin{tabular}{|c|c|c|c|c|c|c|c|c|}
\hline \multirow[t]{2}{*}{$\begin{array}{c}\text { Age-group ... } \\
\text { Age (d)... } \\
\text { No. of pigs } / \text { treatment... }\end{array}$} & \multicolumn{2}{|c|}{$\underset{4}{1}+12 \ddagger$} & & \multicolumn{2}{|c|}{$\begin{array}{c}2 \\
18-21 \\
6\end{array}$} & & \multicolumn{2}{|c|}{$\begin{array}{c}3 \\
27-38 \\
9\end{array}$} \\
\hline & Mean & $\mathrm{SE}$ & & Mean & SE & & Mean & SE \\
\hline Maximal pepsin output $(\mathrm{k} u / h)$ & & & & & & & & \\
\hline Milk-fed & 1.94 & 0.703 & & $\begin{array}{c}4.70 \\
\dagger\end{array}$ & $1 \cdot 330$ & $* *$ & $\begin{array}{c}19 \cdot 39 \\
+\dagger\end{array}$ & $3 \cdot 607$ \\
\hline $\begin{array}{l}\text { Creep-fed } \\
\text { Per unit stomach wt } \\
\text { (k u/g per h) }\end{array}$ & $1 \cdot 41$ & 0.362 & $* *$ & 13.01 & $2 \cdot 327$ & $* * *$ & $43 \cdot 04$ & $5 \cdot 278$ \\
\hline Milk-fed & $0 \cdot 09$ & 0.020 & & $\begin{array}{c}0.16 \\
\dagger\end{array}$ & 0.044 & * & $\begin{array}{c}0.34 \\
+\dagger\end{array}$ & $0 \cdot 050$ \\
\hline $\begin{array}{l}\text { Creep-fed } \\
\text { Per unit body-wt }\end{array}$ & $0 \cdot 08$ & 0.020 & $* *$ & 0.44 & 0.081 & & 0.65 & 0.067 \\
\hline $\begin{array}{l}\text { (k u/kg per h) } \\
\text { Milk-fed }\end{array}$ & 0.53 & $0 \cdot 143$ & & $\begin{array}{c}0.74 \\
+\end{array}$ & $0 \cdot 202$ & $*$ & $\begin{array}{l}1.76 \\
+1+\end{array}$ & $0 \cdot 261$ \\
\hline Creep-fed & 0.50 & 0.132 & * & $2 \cdot 29$ & 0.463 & $* *$ & $4 \cdot 66$ & 0.542 \\
\hline
\end{tabular}

$\ddagger$ Creep-fed pigs receieved only sows' milk up to $12 \mathrm{~d}$.

Differences between age-groups within treatments were significant: ${ }^{*} P<0.05 ; * * P<0.01 ; * * * P<0.001$.

Differences between treatments within age groups were significant: $\dagger P<0.05 ; \dagger \dagger P<0.01 ; \dagger \dagger+P<0.001$.

functional teats and were often observed sucking from more than one teat. In addition, the maximum milk yield in sows occurs between the $3 \mathrm{rd}$ and 5 th week of lactation (Elsley, 1970), and the gross energy content of sows' milk on a dry matter basis is about 1.5 times greater than that of the solid food used. The CF pigs suffered a check in growth rate in the week following weaning, an occurrence which has been reported by many authors (Agricultural Research Council 1967; Leibbrandt et al. 1975; Okai et al. 1976; Whittemore et al. 1978), and although growth rate improved significantly in the 2 nd week post-weaning it was still lower than that of the MF pigs.

\section{Stomach weight}

The stomach weight : body-weight values in pigs 9-38 d old (range $4 \cdot 33-7.74 \mathrm{~g} / \mathrm{kg}$ ) in this experiment are similar to those reported by Lewis et al. (1957), Walker (1959), Braude et al. (1970a), Noakes (1971), Widdowson et al. (1976), Braude (1981) and Cranwell (1984) but are much lower than in the Pitman-Moore miniature-pig $(12.7 \mathrm{~g} / \mathrm{kg})$ reported by Merritt \& Brooks (1970). Significant positive correlations between stomach weight and body-weight have also been reported by Merritt \& Brooks (1970) and Cranwell \& Stuart $(1983 a)$.

The observation that pigs weaned on to solid food (ad lib.) have significantly greater stomach weight:body-weight values than milk-fed pigs is in agreement with the findings of Hartman et al. (1961), Cranwell et al. (1980) and Cranwell (1984). The difference in the rates of gastric development in pigs fed entirely by the sow compared with those fed solid food could be due to a number of factors. These include differences in the physical and chemical nature of the diets, changes in the patterns of feeding and gastric emptying and the effect of weaning. For instance, it is known that pigs reared by the sow suck twenty 
or more times per $24 \mathrm{~h}$ and that during each sucking they receive about $40-50 \mathrm{ml}$ milk (i.e. 8-10 g dry matter; Elsley, 1970; Fraser, 1980). Weaned pigs, on the other hand, have been observed to eat less often (nine to ten times per $24 \mathrm{~h}$ ) and ingest more dry matter per feed (80 g per meal; Auffray \& Marcilloux, 1980).

A number of authors have demonstrated that the rate and pattern of gastric emptying in young pigs can be affected by the physical and chemical nature of the diet and by frequency of feeding (Braude et al. 1970a; Noakes, 1971). Wilson \& Leibholz (1981) reported that the gastric emptying time in pigs given a milk protein diet in a pelleted form was 2.5 times longer than in pigs fed the same diet in a liquid form; frequency of feeding and dry matter intakes were the same for both diets. In the present experiments it is probable that, following sucking or a meal of solid food, the stomachs of the weaned pigs were distended to a greater extent and for longer periods than those of the milk-fed pigs. The trophic effects of gastrin and other hormones in gastric development are discussed later in the paper and it is probably relevant that gastric distension has been shown to be of significant importance in the release of gastrin in the pig (Stadaas \& Schrumpf, 1974; Stadaas et al. 1974).

A limitation of the design of the present experiment was that the reducing litter size probably led to higher than normal milk intakes in the MF pigs. This may have caused greater stomach distension following sucking, and led to an underestimation of the normal differences in stomach development between sucking pigs and weaned pigs.

\section{Acid secretion}

Acid was found in all residual and basal (resting) samples obtained before commencement of Histalog infusion but the amounts found were very variable. The amounts of acid in resting secretions were within the same range as those reported by Tudor et al. (1977) in pigs of similar size and studied using similar techniques. In studies with conscious domestic pigs, $15-50 \mathrm{~kg}$ live weight, in which gastric juice was collected by means of a gastric fistula, basal secretion of acid was also very variable (14-462 $\mu \mathrm{mol} / \mathrm{kg}$ per h) (Muggenburg et al. 1967; Barbezat et al. 1974; Zamora et al. 1975) as was that reported by Merritt \& Brooks (1970) and Moeller et al. (1974) in miniature pigs, 5-37 kg live weight. The factors responsible for basal secretion of acid are not known but Grossman (1978) states that it is likely that tonic vagal stimulation and the constant release of small amounts of gastrin play at least permissive roles. Detectable amounts of gastrin in the blood of fasted young pigs and mature sows have been reported by Cranwell \& Hansky $(1980 a, b)$.

Histalog has been used in a number of studies on gastric secretion in pigs (Tudor et al. 1977; Cranwell et al. 1980; Ticthen et al. 1980; Tudor, 1983; Cranwell \& Stuart, 1983a, b, 1984) and has been found to elicit gastric acid secretory responses in pigs equivalent to or greater than that of other secretagogues (Lambert et al. 1967; Fujita et al. 1980). The pattern of the acid secretory response to Histalog depicted here (Fig. 2) is similar to that found by Tudor (1983) and to the response to histamine infusion in older pigs reported by Barbezat et al. (1974). The initial peak in acid output was reached 45-60 min after commencement of secretogogue infusion and was followed by a levelling off of secretory response. This pattern is similar to that reported by Ward et al. (1963), Zaterka \& Neves (1964), Laudano \& Roncoroni (1965), Laudano (1966), Wruble et al. (1967) and Isenberg et al. (1968) in humans.

It is apparent that the dose rate of Histalog used in the experiments reported here ( $3 \mathrm{mg} / \mathrm{kg}$ per $\mathrm{h}$ ) would have elicited maximal acid secretory responses since it is equivalent to the dose rate of histamine base found to stimulate maximal acid secretion in the miniature-pig (Merritt \& Brooks, 1970) and it has subsequently been found that maximal acid secretion occurs in conscious domestic pigs at dose rates of 3 and $6 \mathrm{mg} / \mathrm{kg}$ per $\mathrm{h}$ 
(Cranwell \& Stuart, 1983a). Similar dose rates of Histalog have been found to elicit maximal acid secretion in humans (Zaterka \& Neves, 1964; Laudano \& Roncoroni, 1965; Wruble et al. 1967).

The acid-secretion studies conducted by Merritt \& Brooks (1970) were with conscious miniature pigs prepared with gastric fistulas and given solid feed. The mean maximal acid output at the dose rate of histamine ( $60 \mu \mathrm{g}$ histamine base $/ \mathrm{kg}$ per $\mathrm{h}$ ) equivalent to the dose rate of Histalog used in the present experiment was 1.28 (SE 0.04) $\mathrm{mmol} / \mathrm{kg}$ per $\mathrm{h}$. In subsequent studies with conscious domestic pigs, 24-37 d old, and prepared with gastric fistulas, Cranwell \& Stuart (1984) found that the mean maximal acid output following infusion of Histalog at $3 \mathrm{mg} / \mathrm{kg}$ per h was 1.64 (sE 0.08$) \mathrm{mmol} / \mathrm{kg}$ per h for pigs weaned on to solid food compared with 1.38 (SE 0.09 ) $\mathrm{mmol} / \mathrm{kg}$ per $\mathrm{h}$ for pigs reared entirely by the sow. These values are somewhat higher than those reported here for pigs of comparable age and treatment, i.e. age group 3 (Table 3 ). The differences may well be related to the different experimental methods used, i.e. anaesthetized acutely-prepared animals $v$. conscious chronically-prepared animals. While there is no evidence that Halothane or barbiturate anaesthesia, or both, have any effect on acid secretion in pigs, it has been variously reported that gastric secretion is unaffected, inhibited or stimulated by a variety of anaesthetic agents in dogs, cats and rats (Geumei \& Danhof, 1976; Albinus et al. 1978). There is also no evidence of what effect chronic gastric cannulation and repeated experimentation has on development of gastric secretion in the young pig.

In studies in other species the maximal histamine response has been found to be a highly significant index of the number of parietal cells (Card \& Marks, 1960; Marks et al. 1960; Myren, 1968). Parietal cell number has also been found to be correlated with the volume (mass) of the fundic mucosa (Card \& Marks, 1960; Crean, 1967). In the miniature pig and domestic pig, Merrit \& Brooks (1970) and Cranwell \& Stuart (1983a) have found significant linear correlations between maximal acid output and fundic mucosal weight. Cranwell \& Stuart $(1983 a$ ) have also reported a significant linear correlation between fundic mucosal weight and stomach weight. The development of acid secretory capacity in the pigs of both treatments in the present study was found to be linearly related to stomach weight, and following the introduction of solid food the CF pigs produced more acid per unit stomach weight than the MF pigs. This would indicate that the total parietal cell mass and the amount of fundic mucosa per unit stomach weight was greater in CF pigs than in MF pigs. Cranwell \& Stuart (1984) have since found that 5-6-week-old CF pigs had significantly more fundic mucosal tissue than MF pigs of the same age and similar live weights.

\section{Pepsin secretion}

The occurrence of pepsin in the basal (resting) secretions following a period of fasting is in agreement with the observations made by Merritt \& Brooks (1970), Noakes (1971) and Barbezat et al. (1974) and could be related to the presence of acid in these secretions (Johnson, 1972; Bynum \& Johnson, 1975; Webber \& Morrissey, 1980).

Information on porcine gastric secretion of proteolytic enzymes, as distinct from reports of proteolytic enzyme concentrations in the gastric mucosa or gastric contents, is relatively limited. Studies have been carried out in the miniature pig (Merritt \& Brooks, 1970); domestic pigs, 15-40 kg live weight (Barbezat et al. 1974; Low, 1982); domestic pigs prepared with Heidenhain pouches (Noakes, 1971; Cranwell \& Titchen, 1976); and totally isolated perfused porcine stomachs (Kowalewski et al. 1974). In two of these studies (Merritt \& Brooks, 1970; Barbezat et al. 1974), in which histamine was used as a secretagogue, maximal output of pepsin occurred at the dose rate of histamine equivalent to the dose rate of Histalog used in the present experiment. In subsequent studies with conscious domestic pigs, $12-37 \mathrm{~d}$ old, and prepared with gastric fistulas, Cranwell \& Stuart (1983b) found that 
maximal pepsin output following infusion of Histalog occurred at a dose rate of $6 \mathrm{mg} / \mathrm{kg}$ per $\mathrm{h}$. Although pepsin output at $3 \mathrm{mg} / \mathrm{kg}$ per $\mathrm{h}$ was lower, the difference was small and not statistically significant.

The results presented here are in agreement with the findings of authors referred to in the introduction and show that gastric secretory capacity of pepsin is low in pigs up to about 3-4 weeks of age and then undergoes a very rapid increase. This pattern of development is reflected by the results of Braude et al. (1970 b) and Leibholz (1981) which show that the 28-d-old pig has only a limited ability to hydrolyse dietary protein in the stomach, and the later findings of Leibholz (1984) that this ability increases markedly during the next $28 \mathrm{~d}$ so that at $56 \mathrm{~d}$ of age about $50 \%$ of dietary protein (milk) is hydrolysed in the stomach. The capacity of the stomach to hydrolyse dietary protein continues to increase to at least $150 \mathrm{~d}$ of age (Zebrowska, 1973). In addition to age, the results of the present study also show that access to solid food before weaning and weaning on to solid food have significant positive effects on the capacity of the stomach to secrete pepsin thus confirming the earlier reports of Hartman et al. (1961), Decuypere et al. (1978) and Efird et al. (1982).

It was evident that the pattern of development of secretory capacity for acid differed from that for pepsin. Acid output per unit stomach tissue decreased throughout the period of the experiment in the case of the MF pigs and remained relatively constant after the introduction of solid food in the CF pigs (Table 3), whereas in pigs in both treatments pepsin output per unit stomach tissue increased with both age and stomach weight (Table 4). Thus if acid and pepsin secretory capacity is related to the total number of parietal and peptic (chief) cells respectively, this would indicate the number of parietal cells per unit stomach tissue changes slowly with age whereas the number of peptic cells per unit stomach tissue increases rapidly with age. Confirmation of this supposition awaits a quantitative histological study.

\section{Hormones and gastric development}

The evidence presented here indicates that pigs given access to solid food before weaning and weaned on to solid food have larger stomachs and greater acid and pepsin secretory capacities than pigs fed entirely on sows' milk. The factors responsible for the observed differences in rates of gastric development have been discussed earlier and could well be mediated by hormones.

Humoral agents are probably involved in the development of the pig stomach since acid and proteolytic enzyme secretions from isolated, denervated, fundic pouches increased during the first 6 weeks of life (Cranwell \& Titchen, 1976). Cranwell \& Hansky $(1980 a, b)$ have found that basal (fasting) serum gastrin levels are higher in both weaned and sucking pigs than in adult animals and that the postprandial response to intake of food is greater in pigs fed solid food than in those suckled by the sow. Gastrin is a trophic hormone for the fundic mucosa (particularly parietal cells) in adult animals (Johnson, 1981) and could therefore be acting in this way in young developing pigs.

Other hormones implicated in the development of the stomach are adrenocorticotrophic hormone and the corticosteroids which cause an increase in the proteolytic enzyme content of the gastric mucosa in rats and mice (Furihato et al. 1972; Tatematsu et al. 1975; Kumegawa et al. 1978; Pelletier et al. 1983). Weaning can be a time of stress for the pig resulting in prolonged rises in plasma cortisol concentrations (Worsaae \& Schmidt, 1980). However, single glucocorticoid injections at different doses and ages (3-17 d) had no significant effect on the proteolytic activity of the gastric mucosa in pigs (Pelletier et al. 1983).

A number of reports suggest that thyroxine is a permissive hormone in the development of gastrointestinal enzyme activity (Kumegawa et al. 1980; Henning, 1981; Baintner \& 
Nemeth, 1982) and epidermal growth factor has been identified as a potent trophic hormone for the fundic mucosa (Johnson, 1981). Thus gastrin and the corticosteroids are probably not the only hormones or agents involved in the maturation of the gastric mucosa.

The author wishes to thank Gary W. Johnston for his skilled technical assistance and for carrying out the pepsin analyses, Linda Foulds for carrying out the acid titrations and $\mathrm{Dr}$ J. J. Quilkey for statistical advice. The research was supported by a grant from the Australian Pig Industry Research Committee.

\section{REFERENCES}

Agricultural Research Council (1967). The Nutrient Requirements of Farm Livestock, no. 3 Pigs. London: Agricultural Research Council.

Albinus, M., Blair, E. L., Hirst, B. H. \& Reed, J. D. (1978). Journal of Physiology 274, 1-8.

Auffray, P. \& Marcilloux, J. C. (1980). Reproduction, Nutrition, Developpement 20, 1625-1632.

Baintner, K. \& Nemeth, A. (1982). Archiv für Tierernährung 32, 229-234.

Barbezat, G. O., Waterworth, M. W., Daniel, M., Bank, S. \& Terblanche, J. (1974). South African Medical Journal 48, 1985-1990.

Braude, R. (1981). Progress in Clinical and Biological Research 77, 841-846.

Braude, R., Dollar, A. M., Mitchell, K. G., Porter, J. W. G. \& Walker, D. M. (1958). Proceedings of the Nutrition Society 17, 49-50.

Braude, R., Mitchell, K. G., Newport, M. J. \& Porter, J. W. G. (1970a). British Journal of Nutrition 24, $501-516$. Braude, R., Newport, M. J. \& Porter, J. W. G. (1970 b). British Journal of Nutrition 24, $827-842$.

Brownlee, K. A. (1965). Statistical Theory and Methodology in Science and Engineering. New York: John Wiley. Bynum, T. E. \& Johnson, L. R. (1975). American Journal of Digestive Diseases 20, 607-612.

Card, W. I. \& Marks, I. N. (1960). Clinical Science 19, 147-163.

Cranwell, P. D. (1977). Proceedings of the Nutrition Society 36, 142A.

Cranwell, P. D. (1984). Proceedings of the Australian Society of Animal Production 15, 145-157.

Cranwell, P. D. \& Hansky, J. (1980a). Research in Veterinary Science 29, 85-88.

Cranwell, P. D. \& Hansky, J. (1980b). Proceedings of the International Pig Veterinary Society, 6th Congress, Copenhagen, p. 76.

Cranwell, P. D., Noakes, D. E. \& Hill, K. J. (1976). British Journal of Nutrition 36, 71-86.

Cranwell, P. D., Shaughnessy, J. J. \& Smith, R. E. (1980). Proceedings of the Nutrition Society 39,93 A.

Cranwell, P. D. \& Stuart, S. J. (1983a). Proceedings of the Australian Physiological and Pharmacological Society 14, 39P.

Cranwell, P. D. \& Stuart, S. J. (1983b). Proceedings of the Nutrition Society of Australia 8, 134.

Cranwell, P. D. \& Stuart, S. J. (1984). Proceedings of the Australian Society of Animal Production 15, 669.

Cranwell, P. D. \& Titchen, D. A. (1974). Research in Veterinary Science 16, 105-107.

Cranwell, P. D. \& Titchen, D. A. (1976), Proceedings of the Nutrition Society 35, 28 A.

Crean, G. P. (1967). In Gastric Secretion, pp. 33-43 [T. K. Shnitka, J. A. L. Gilbert and R. C. Harrison, editors]. Oxford: Pergamon Press.

Decuypere, J. A., Bossuyt, R. \& Henderickx, H. K. (1978). British Journal of Nutrition 40, 91-102.

Efird, R. C., Armstrong, W. D. \& Herman, D. L. (1982). Journal of Animal Science 55, 1380-1387.

Elsley, F. W. H (1970). In Lactation, pp. 393-411 [I. R. Falconer, editor]. London: Butterworths.

Foltmann, B., Jensen, A. L., Lonblad, P., Smidt, E. \& Axelsen, N. H. (1981). Comparative Biochemistry and Physiology 68B, 9-13.

Foltmann, B., Lonblad, P. \& Axelsen, N. H. (1978). Biochemical Journal 169, 425-427.

Forte, J. G., Forte, T. M. \& Machen, T. E. (1975). Journal of Physiology 244, 15-31.

Fourie, J., Arnot, R. S., Carter, J., Hickman, R. \& Terblanche, J. (1974). South African Medical Journal 48, 1873-1875.

Fraser, D. (1980). Applied Animal Ethology 6, 247-255.

Friend, D. W., Cunningham, H. M. \& Nicholson, J. W. G. (1963). Canadian Journal of Animal Science 43, $174-181$. Fujita, S., Kokue, E.-I., Kurebayashi, Y. \& Hayama, T. (1980). Japanese Journal of Veterinary Science 42, 401-406.

Furihato, C., Kawachi, T. \& Sugimura, T. (1972). Biochemical and Biophysical Research Communications 47, $705-711$.

Geumei, A. \& Danhof, I. E. (1976), Federation Proceedings 35, 539.

Grossman, M. I. (1978). Gastrointestinal Disease, vol. 1, pp. 640-659. Philadelphia: W. B. Saunders.

Hartman, P. A., Hays, V. W., Baker, R. O., Neagle, L. H. \& Catron, D. V. (1961). Journal of Animal Science 20, $114-123$.

Henning, S. J. (1981). American Journal of Physiology 241, G199-G214. 
Isenberg, J. I., Brooks, A. M. \& Grossman, M. I. (1968). Journal of the American Medical Association 206, 2897-2898.

Johnson, L. R. (1972). American Journal of Physiology 223, 847-850.

Johnson, L. R. (1981). In Physiology of the Gastrointestinal Tract, pp. 169-196 [L. R. Johnson, editor]. New York: Raven Press.

Kidder, D. E. \& Manners, M. J. (1978). Digestion in the Pig. Bristol: Scientechnica.

Kowalewski, K., Secord, D. C. \& Koledej, A. (1974). Canadian Journal of Surgery 17, 340-347.

Kumegawa, M., Takuma, T., Hosoda, S., Kunii, S. \& Kanda, Y. (1978). Biochimica et Biophysica Acta 543, 243-250.

Kumegawa, M., Yajima, T., Maeda, N., Takuma, T. \& Hosoda, S. (1980). Journal of Endocrinology 87, 431-435.

Lambert, R., Decultieu, A., Andre, C. \& Martin, F. (1967). Compte Rendu des Séances de la Sociéte de Biologie, Paris 161, 1712-1715.

Laudano, O. M. (1966). Gastroenterology 50, 653-656.

Laudano, O. M. \& Roncoroni, E. C. (1965). Gastroenterology 49, 372-374.

Leibbrandt, V. D., Ewan, R. C., Speer, V. C. \& Zimmerman, D. R. (1975). Journal of Animal Science 40, $1077-1080$.

Leibholz, J. (1981). British Journal of Nutrition 46, 59-69.

Leibholz, J. (1984). Proceedings of the Australian Society of Animal Production 15, 145-157.

Lewis, C. J., Hartman, P. A., Liu, C. H., Baker, R. O. \& Catron, D. V. (1957). Journal of Agricultural and Food Chemistry 5, 687-690.

Low, A. G. (1982). British Journal of Nutrition 48, 147-159.

Marks, I. N., Komarov, S. A. \& Shay, H. (1960). American Journal of Physiology 199, 579-588.

Merritt, A. M. \& Brooks, F. P. (1970). Gastroenterology 58, 801-814.

Moeller, H., Sewing, K:Fr., Giesbe, H. \& Schmolke, M. (1974). Naunyn-Schmiedebergs Archiv für Pharmakologie 283, 83-92.

Muggenburg, B. A., Reimann, E. M., Kowalczyk, T. \& Hoekstra, W. G. (1967). American Journal of Veterinary Research 28, 1427-1435.

Myren, J. (1968). In The Physiology of Gastric Secretion, pp. 418-428. [L. S. Semb and J. Myren, editors]. Oslo: Universtitetsforlaget.

Noakes, D. E. (1971). Gastric function in the young pig. PhD Thesis, University of London.

Okai, D. B., Aherne, F. X. \& Hardin, R. T. (1976). Canadian Journal of Animal Science 56, 573-586.

Ostle, B. (1963). Statistics in Research. Ames, Iowa: Iowa State University Press.

Pelletier, G., Lanoe, J., Filion, M. \& Dunnigan, J. (1983). Journal of Animal Science 57, 74-81.

Seve, B. \& Laplace, J.-P. (1975). Annales de Zootechnie 24, 43-57.

Simoes-Nunes, C. (1982). In Digestive Physiology in the Pig, pp. 133-151. [J. P. Laplace, T. Corring and A. Rerat, editors]. Paris: INRA.

Stadaas, J. \& Schrumpf, E. (1974). Scandinavian Journal of Gastroenterology 9, 781-785.

Stadaas, J., Schrumpf, E. \& Haffner, J. F. W. (1974). Scandinavian Journal of Gastroenterology 9, $127-131$.

Starovojtov, A. M. (1956). Zivotnovodstvo 6, 46-51.

Tatematsu, M., Takahashi, M., Tsuda, H., Hirose, M., Furihata, C. \& Sugimura, T. (1975). Cell Differentiation 4. 285-294.

Titchen, D. A., Tudor, E., McI. \& Schofield, G. G. (1980). In Scientific Foundations of Veterinary Medicine, pp. 247-253. [A. T. Phillipson, L. W. Hall and W. R. Pritchard, editors]. London: Heinemann.

Tudor, E. McI. (1983). Studies on the gastric mucosa of young pigs. PhD Thesis, Monash University.

Tudor, E. McI., Schofield, G. C. \& Titchen, D. A. (1977). Annales de Recherches Veterinaires 8, $450-459$.

Walker, D. M. (1959). Journal of Agricultural Science 52, 352-356.

Ward, S., Gillespie, I. E., Passaro, E. P. \& Grossman, M. I. (1963). Gastroenterology 44, 620-626.

Webber, D. E. \& Morrissey, S. M. (1980). Experientia 36, 989-990.

Whittemore, C. T., Aumaitre, A. \& Williams, I. H. (1978). Journal of Agricultural Science, Cambridge 91, 681-692.

Widdowson, E. M., Colombo, V. E. \& Artavanis, C. A. (1976). Biology of the Neonate 28, $272-281$.

Wilson, R. H. \& Leibholz, J. (1981). British Journal of Nutrition 45, 321-336.

Worsaae, H. \& Schmidt, M. (1980). Acta Veterinaria Scandinavica 21, 640-657.

Wruble, L. D., Cummins, A. J., Goldenberg, J. \& Schapiro, H. (1967). American Journal of Digestive Diseases 12, $1087-1090$.

Zamora, C. S., Kowalczyk, T., Hoekstra, W. G., Grummer, R. H. \& Will, J. A. (1975). American Journal of Veterinary Research 36, 33-39.

Zaterka, S. \& Neves, D. P. (1964). Gastroenterology 47, 251-257.

Zebrowska, T. (1973). Rocznik Naukro Rolniczych Seria B Zootechniczna 95 (1), 115-131. 